\title{
How CPED Guiding Principles and Design Concepts Influenced the Development and Implementation of an EdD Program
}

\author{
Ray R. Buss, PhD \\ Mary Lou Fulton Teachers College \\ Arizona State University \\ ray.buss@asu.edu
}

\begin{abstract}
In this essay, I have described how the CPED Guiding Principles for Program Design (GPPD) and Design Concepts (DC) have influenced the development and implementation of Arizona State University's EdD in Leadership and Innovation program. I have explained the pervasive influence of the CPED GPPD and DC on various aspects of the program including (a) more general or global aspects of the program; (b) signature pedagogies of the program; (c) development of program milestones; and (d) development and implementation of courses in the program. As a result, faculty members have created and continue to deliver a more coherent, practitioner-oriented program, which benefits students and is guided by the CPED Principles and Design Concepts.
\end{abstract}

KEYWORDS: CPED, CPED Guiding Principles for Program Design and Concepts, EdD programs, practitioner-oriented EdD programs

\section{INTRODUCTION}

When the Carnegie Project on the Education Doctorate (CPED) came together in 2007, the consortium sought to better differentiate between the outcomes and expectations for EdD and PhD candidates. .... [Over time, CPED and its member institutions have] redefine[d] the EdD and the preparation that produces educational leaders that transform practice. (Perry, 2016, p. 2)

How have education faculty members constructed and implemented redesigned doctoral programs to develop educational leaders who can appropriately transform practice? In particular, for those pursuing the EdD, how have faculty members and programs provided meaningful doctoral experiences for practicing educators who seek to improve their settings to be more effective for those whom they serve?

Some reflection on these questions clearly indicated the nature of the experiences should be quite different for EdD program participants than the experiences provided to those seeking the PhD. Yet, that typically has not been the case (Perry, 2012, 2016; Perry \& Imig, 2008). In numerous studies, researchers have suggested educational leaders frequently have been prepared in programs that were not appropriate to meet their needs (Levine, 2005; Shulman, Golde, Bueschel, \& Garabedian, 2006). Fortunately for educators seeking the EdD degree, more than 100 Carnegie Project on the Education Doctorate (CPED) affiliated programs have been (re)designed to better meet practicing educators' needs (Buss, Zambo, Zambo, Perry, \& Williams, 2017; Buss, Zambo, Zambo, \& Williams, 2014; Hoffman \& Perry, 2016; Perry, 2012, 2016; Perry,
Zambo, \& Wunder, 2015; Zambo, Zambo, Buss, Perry, \& Williams, 2014). In this essay, I have described how the CPED Frameworkthe Guiding Principles for Program Design (GPPD) and Design Concepts (DC) - has been used to (a) influence the design of Arizona State University's EdD in Leadership and Innovation program and its delivery, (b) develop our program milestones, which have served as a means to assess students' progress throughout the program, and (c) shape our courses. (Note: Perry and Zambo fully described the CPED GPPD and DC in the introduction to these articles). The influence of the CPED Framework has continued as program faculty have implemented and continually refined the program to serve educational leaders more effectively. Before I discuss the influence of the CPED Framework on this EdD program, it will be instructive to consider how EdD programs can best be responsive to the needs of scholarly practitioners. In this discussion, of course, the tension between students' needs and faculty members' considerations of what would be fitting to ensure appropriate doctoral preparation was a critical factor in designing and implementing the program. In the design and implementation of the current program, consideration of students' needs as continuing leaders in various educational settings as well as the CPED Framework were carefully contemplated.

\section{THE CHALLENGE}

In the next section, I documented the need to develop scholarly practitioners. In particular, I focused on developing appropriate practice-related skills for scholar practitioners.
New articles in this journal are licensed under a Creative Commons Attribution 4.0 United States License.

This journal is published by the University Library System of the University of Pittsburgh as part of its D-Scribe Digital Publishing Program and is cosponsored by the University of Pittsburgh Press.

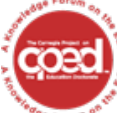

This journal is supported by the Carnegie Project on the Education Doctorate: A Knowledge Forum on the EdD (CPED) cpedinitiative.org 


\section{Developing Scholarly Practitioners in EdD Programs}

Levine (2005) and Shulman et al. (2006) have amply documented problems with respect to inappropriate and inadequate preparation of educational leaders in EdD programs. For example, Levine criticized EdD programs for irrelevant curriculum; deficient clinical preparation; unsuitable research preparation of students that was not applicable to their work settings as school leaders; low quality research and dissertations; and so on. Levine attributed the inappropriate preparation to programs that were a confused combination of $\mathrm{PhD}$ and $\mathrm{EdD}$ programs with undifferentiated outcomes. For example, Levine claimed the majority of programs inappropriately prepared school leaders as more traditional researchers; rather than preparing them to engage in meaningful research work connected to their daily practices. Shulman and his colleagues (2006) offered similar criticisms of EdD programs including a strong critique about the mismatch between preparation and career paths. Specifically, Shulman et al. suggested this poor preparation resulted in "offering [EdD students] experiences more similar to PhD programs than to the high-level preparation for practice or leadership found in other learned professions" (p. 27).

In this influential article, Shulman et al. (2006) advocated for the development of a new degree, the Professional Practice Doctorate (PPD). Although use of the term did not "catch on," the article and the thinking it represented were instrumental in directing the emergence and development of CPED and CPED GPPD and DC, which have influenced the (re)design of many EdD programs. Further, Shulman and his colleagues proposed ways to develop new or revised doctoral programs, which emphasized serving the needs of professional practitioners. They offered a set of fundamental characteristics to distinguish these new, practitioner-focused programs that included (a) employing signature pedagogies, (b) requiring development of practice-related research skills, (c) expecting program participants to be engaged in prior and ongoing practice experiences, and (d) suggesting individuals participating in such programs "would be skilled in carrying out local research and evaluations to guide practice" (p. 29). Clearly, these characteristics provided a beginning point for discussions about necessary properties or features of programs that were consistent with the unique needs of degree-seeking, educational practitioners who wanted to influence their practices. Importantly, these seminal recommendations for the (re)design of EdD programs served as the impetus for devising the more fully articulated CPED Framework, which faculty members from the initial 25 colleges of education that participated in CPED deliberated and developed.

\section{The Carnegie Project on the Education Doctorate}

Faculty members from CPED-affiliated colleges of education have collaborated since 2007 to reenvision and reclaim the EdD as the relevant terminal, professional degree for educational leaders (Buss et al., 2017; Hoffman \& Perry, 2016; Perry, 2012, 2016; Perry \& Imig, 2008; Zambo et al., 2014). By drawing upon the CPED Framework, taking into account local contexts, and considering students' needs and faculty members' visions for programs, CPEDaffiliated colleges of education have developed new EdD programs to meet better the needs of practicing educational professionals.

The goal of CPED-guided EdD programs has been to develop educational leaders, scholarly practitioners, those individuals who combined practical wisdom, professional knowledge, and work- related research skills to identify, frame, and solve problems of practice in their workplace settings (CPED, 2009). To provide direction in attaining this goal, faculty members from CPED-guided colleges of education collaborated to create a set of six GPPD for reenvisioned EdD programs (CPED, 2009). As a result, faculty members of CPED-guided programs have used the six CPED GPPD to (re)design EdD programs.

In addition to the direction provided by the six GPPD, CPEDguided programs have employed CPED DC such as (a) problem of practice, (b) scholarly practitioner, (c) signature pedagogy, (d) inquiry as practice, (e) laboratories of practice, and (f) dissertations in practice (CPED, 2010). Use of the six GPPD and six DC has resulted in extensively (re)designed EdD programs throughout the United States (Buss et al., 2014, 2017; De Lisi, 2013; Macintyre Latta \&Wunder, 2012; Perry, 2012, 2016; Rueda, Sundt, \& Picus, 2013; Sawyer, 2013; Susman Israel, Sostak, Stewart, \& BazziMoughania, 2016; Zambo et al., 2014).

\section{USING THE CPED FRAMEWORK TO GUIDE AN EDD PROGRAM}

In the following three sections, I have described and explained how the CPED Framework has influenced our EdD program. First, I have explained the influence it has had on our program design and its delivery in global ways and subsequently with respect to two signature pedagogies. Second, I have described how the CPED Framework influenced development of program milestones. Third, I have explicated the influence of the CPED Framework on our courses and provided several examples to illustrate those effects.

\section{Influence of the CPED Framework on Global Aspects of Program Design and Delivery}

The CPED Framework has extensively influenced the EdD program at Arizona State University. In this section, I have described how the CPED Framework shaped four fundamental facets of our program. Those four key features of the program included (a) using problems of practice, which has been central to the program; (b) developing scholarly and influential practitioners, the overall program goal; and describing the two key signature pedagogies (Shulman, 2005) of the program-(c) cycles of action research (CAR) and (d) Leader Scholar Communities (LSC).

I chose to write about these four features because they have been at the center of the program and influenced other aspects of the program like course content, course requirements, learning activities, student products, and so on. Thus, these four features have served as the skeleton around which the program and its components were articulated. Further, these features have ensured program meaningfulness, continuity, and coherence. Finally, and notably, these four features may be useful to those who are redesigning their EdD program or for those who wish to adapt them for use in a recently (re)designed EdD program.

Problem of Practice (PoP). CPED's (2010) PoP Design Concept has been a central feature of our program from the beginning. Students have come to the program with a PoP situated in their workplace setting, one that they wanted to improve or resolve. For example, one high school English teacher at a small rural high school developed English class work to foster collegegoing skills and behaviors to increase the number of students from 
that high school to go on to post-secondary education. Another student worked with methods course instructors in a teacher preparation program to infuse English as a second language strategies into those courses so that teacher candidates would be better prepared to teach English language learners when they lead their own classrooms. As illustrated in these examples, CPED Principle 1 on social justice or equity issues around a PoP, served as the impetus for many of the students' PoP. Clearly, in terms of Principle 2, students' work on the PoP afforded them opportunities to make positive differences in the lives of others.

Further, the program's reliance on the PoP has resulted in other beneficial outcomes. By drawing upon the PoP, the program has encouraged students to connect and apply what they were learning in the program to their PoP in their field-based settings. Therefore, program designers and faculty members have afforded students opportunities to apply CPED Principle 4 as they analyzed their PoP and used multiple approaches to devise and test solutions for it. Moreover, with respect to CPED Principle 5, as students worked on their PoP, they capitalized on opportunities to develop their professional knowledge bases, integrate practical and research knowledge, and link that to systematic inquiry. Finally, as students have worked on their PoP, they generated and used professional knowledge in their practices, CPED Principle 6.

Developing scholarly and influential practitioners. The overall goal of the ASU EdD in Leadership and Innovation program has been to develop scholarly and influential practitioners: those individuals who were able to learn effectively, lead change, and improve local situations (CPED, 2009) using action research. Given these objectives, the program has employed a conventional cohort approach and two signature pedagogies based on the CPED Framework. We have used a cohort structure based on Wenger's community of practice (CoP) perspective (Wenger, 1998; Wenger, McDermott, \& Snyder, 2002). When students began the program, they worked in appropriate community of practice contexts, initially in a large group of 20-22 students and later in smaller leader scholar communities (LSC, see the description below) of five to seven students and one faculty member.

Requiring students to engage in the cohort work and discussions reflected several CPED GPPD including Principles 2, 3, and 5. Specifically, the cohort work fostered collaboration and communication skills, CPED Principle 3, necessary for working with diverse communities and building partnerships. Notably, the collaboration developed in the cohort work extended to the practice communities of program participants, which allowed them to work more effectively within their own CoP (Wenger, 1998; Wenger et al., 2002). This collaborative work also has supported program participants as they applied their efforts to effect positive changes in individuals, organizations, or communities, CPED Principle 2. For example, most students in the program have developed their own communities of practice as they attempted to implement innovations to effect changes with respect to their PoP. Finally, with respect to Principle 5, the cohort work has been useful in extending the professional knowledge base of students and affording them opportunities to integrate practical and research knowledge as they discussed and defended their emerging knowledge of theories and inquiry practices.

In addition to the more general approaches such as the PoP and the cohort method described above, our program has employed two signature pedagogies (Shulman, 2005) that pervasively have influenced the experiences of students in the program. Again, CPED GPPD deeply influenced these signature pedagogies. Because the program capitalized on students' PoP and its resolution, workplaces have served as students' laboratories of practice, one of the CPED (2010) design concepts. Further, the program has employed cycles of action research (CAR) to provide opportunities for students to delve deeply into their PoP as they seek a resolution to it. Thus, CAR has served as our first signature pedagogy. The program has utilized leader scholar communities (LSCs) as our second signature pedagogy. These signature pedagogies were consistent with Shulman et al.'s (2006) first characteristic of strong professional doctoral programs that suggested such programs employed signature pedagogies that graduates would meaningfully and readily use after the program. Thus, our selection and use of these specific signature pedagogies-CAR and LSCs were applicable during the program and importantly afterword as graduates were engaged in their day-to-day educational practice settings.

Cycles of action research. Throughout our program, we have employed on-going CAR (Buss, 2018; Buss \& Zambo, 2016). The use of CAR has afforded opportunities for students to develop practice-appropriate inquiry strategies closely connected to their workplace settings (Buss, 2018). Faculty members introduced CAR early in the program and expanded on them throughout. Again, based on their PoP, students have engaged in efforts where they explored the literature for practical solutions, engaged in some intervention/innovation, gathered and analyzed data, determined their outcomes, and decided about their next steps. Students have continued this cyclical process throughout the program. An action research dissertation in practice (DiP) has served as the culminating experience. Further, CAR ensured students were conducting research in the local setting to guide practice. Moreover, requiring students to engage in on-going CAR throughout the program, affords many opportunities for program participants to develop inquiry skills that carry over into professional practice upon completion of the program (Buss, 2018). Taken together, the CAR approach was consistent with a number of the CPED principles.

Specifically, it was clear that CAR, which were based on the students' PoP from their workplaces, have provided occasions for students to engage in work related to equity and social justice, CPED Principle 1. Further, CAR have offered situations in which students have constructed and applied knowledge to their PoP to make a positive difference in the lives of their students, those whom they serve, or their organizations, Principle 2. Moreover, CAR have provided opportunities for students to develop and employ collaboration skills and build partnerships, CPED Principle 3, to implement and conduct their action research work during the program and afterword. For example, most students' projects have included working with staff member colleagues to improve achievement at a grade-level or school site, improve student services staff members' skills to support transfer students, or create more effective professional development for colleagues.

Notably, CAR have provided field-based opportunities for students to analyze their PoP, and use multiple frames to develop meaningful solutions, CPED Principle 4. For example, students in the program conduct reconnaissance in an early CAR and then use that information to assist them in better understanding the problem and developing initial thinking about their intervention to combat the PoP. Through their work on their PoP, students also integrated knowledge of practice from their workplace with research knowledge 
as they linked theory and systematic inquiry, CPED Principle 5. Simultaneously, the CAR provided students with opportunities to engage in generating, transforming, and using professional knowledge and practice, CPED Principle 6.

Leader-scholar communities. LSCs have been the second signature pedagogy, which we have used to support students during the latter portion of the program as they completed comprehensive examinations, DiP proposals, the DiP, and its defense. Beginning in the second year of our three-year program, students became members of a LSC. A LSC was comprised of five to seven students and one faculty member who served as chair of all these students' DiP committees. There were two primary functions of the LSCs. First, LSCs provided a method to support students as they developed their DiP proposals, conducted the dissertation work, and completed data analysis and writing of the final DiP. Second, LSCs provided a means for students to remain connected to the program, student peers, and faculty members to assist them in completing these DiP efforts. To achieve these outcomes, members of the LSCs met regularly, learned together, and supported each other academically, socially, and emotionally (Amrein-Beardsley et al., 2012; Buss \& Allen, 2018; Olson \& Clark, 2009). For a detailed description of LSCs and their implementation, see Buss and Allen (2018).

For example, regularly scheduled LSC meetings provided students with academic support by incorporating topics such as relevant theories for dissertation work, methodologies for instrumentation and data analysis, writing processes, and so on. Faculty members and students supported one another socially and emotionally through social networks where they were engaged in face-to-face and now also in online contact for our online students, which ensured students remained connected to the program during the dissertation phase of study (Ali \& Kohun, 2007). The use of LSCs was consistent with CPED Principles 3, 5, and 6. The LSCs provided occasions for students to employ collaboration and communication skills to build partnerships, CPED Principle 3 . In some instances, LSC members formed their own dyads and triads who worked together in their own communities of practice where they exchanged ideas, reviewed one another's work, and supported their colleagues. The LSC meetings presented numerous opportunities for members to develop professional knowledge that integrated practical and research knowledge, CPED Principle 5, as they discussed their PoP and what theories might be useful in helping them to better conceptualize their PoP or their intervention to effect change in their PoP. Finally, discussion and interaction during the LSCs afforded opportunities for students to consider and explore the use of professional knowledge and practice to effect transformations in their workplace settings, CPED Principle 6. As noted above, students formed their own CoP in their work places as they worked to resolve their PoP.

\section{Influence of the CPED Framework on Program Milestone Development and Assessment}

The CPED Framework was critical in the development of program milestones. It guided faculty members as they considered how to devise milestones based on program goals that would effectively assess the progress of students in the program. Employment of the CPED Framework for this purpose allowed faculty members to take more general program outcomes-(a) becoming strong leaders, (b) serving as change agents, (c) becoming data-informed decision makers, and (d) working as collaborators in their settings-and create specific leadership and, innovation/research milestones that could be assessed throughout the program. Examples of leadership milestones included a professional growth plan; leadership challenge reflection; a postdegree impact plan, and so on (see the upper part of Table 1). By comparison, innovation/research milestones included context of problem of practice analysis; internal research presentations; a DiP, and so on (see the lower portion of Table 1). Further, the connections between the CPED Framework and the program milestones has been denoted in Table 1 by an ' $X$ ' in the row of the milestone under the column of the CPED guiding principle or design concept, which applied to that milestone.

\section{Influence of CPED framework on leadership}

milestones. As an illustration of the influence of the CPED Framework, consider the professional growth plan, the first leadership milestone presented in Table 1. Faculty members regarded CPED Principles 1, 2, 4, and 6 to be influencing the professional growth plan required of students near the beginning of the program. Specifically, in the growth plan, students have been required to address matters of equity and social justice, CPED Principle 1, as they considered professional growth to address better these matters in their practices. Moreover, students had to indicate how they planned to develop leadership skills to apply knowledge to make a positive difference in their students, families, organizations, or communities, CPED Principle 2. Similarly, with respect to CPED Principle 4, students developed a growth plan that included information about how they would use field-based opportunities to work on their PoP. Finally, with regard to CPED Principle 6, students were required to develop a growth plan with information about how they intended to use professional knowledge and practice to transform their practice.

With respect to CPED DC, as students developed their professional growth plans, their thinking and writing was concerned with matters such as their PoP; investigating their PoP by conducting inquiry as practice; and carrying out this work in their workplace settings, that is to say, their laboratories of practice. Of course, all of the activities related to the exercise of developing a growth plan contributed to the development of students as scholarly practitioners as they blended their practical wisdom with professional skills to identify and solve PoP while they were collaborating with key stakeholders.

\section{Influence of CPED framework on innovation/action} research milestones. An example of an innovation/research milestone was the online research conference presentations (Mertler \& Henriksen, 2018), which have been required three times throughout the program, at the end of each year of the students' program. In their presentations, first- and second-year students have described the action research efforts they have conducted during the current semester. By comparison, third-year students have presented on their dissertations in practice. With respect to the CPED Framework, CPED Principles 2, 3, and 4 guided the development and use of the research conference presentations in the program milestones. In their presentations, students have described how their action research efforts have made differences in individuals, organizations, or communities, CPED Principle 2. Further, they have provided information about how they have collaborated with their communities and built partnerships to deal 
Table 1. Program Milestones by CPED Guiding Principles and Design Concepts

\begin{tabular}{|c|c|c|c|c|c|c|c|c|c|c|c|c|}
\hline & \multicolumn{6}{|c|}{ CPED Guiding Principles } & \multicolumn{6}{|c|}{ CPED Design Concepts } \\
\hline & $\begin{array}{l}1 \\
\text { Equity, } \\
\text { Ethics, } \\
\& \\
\text { Social } \\
\text { Justice } \\
\text { for } \\
\text { POPs }\end{array}$ & $\begin{array}{l}2 \\
\text { Make a } \\
\text { Positive } \\
\text { Difference }\end{array}$ & $\begin{array}{l}3 \\
\text { Collaborate } \\
\text { \& Comm. } \\
\text { Skills to } \\
\text { Build } \\
\text { Partnerships }\end{array}$ & $\begin{array}{l}4 \\
\text { Field-based } \\
\text { Opportunities } \\
\text { to Analyze } \\
\text { POP and Its } \\
\text { Resolution }\end{array}$ & $\begin{array}{l}5 \\
\text { Integrate } \\
\text { Practical \& } \\
\text { Research } \\
\text { Knowledge }\end{array}$ & $\begin{array}{l}6 \\
\text { Generate, } \\
\text { Transform, } \\
\text { and Use } \\
\text { Professional } \\
\text { Knowledge } \\
\text { \& Practice }\end{array}$ & $\begin{array}{l}\text { Problem } \\
\text { of } \\
\text { Practice }\end{array}$ & $\begin{array}{l}\text { Scholarly } \\
\text { Practitioner }\end{array}$ & $\begin{array}{l}\text { Signature } \\
\text { Pedagogy }\end{array}$ & $\begin{array}{l}\text { Inquiry } \\
\text { as } \\
\text { Practice }\end{array}$ & $\begin{array}{l}\text { Laboratories } \\
\text { of Practice }\end{array}$ & $\begin{array}{l}\text { Dissertation } \\
\text { in Practice }\end{array}$ \\
\hline \multicolumn{13}{|l|}{$\begin{array}{l}\text { Leadership } \\
\text { Milestones }\end{array}$} \\
\hline $\begin{array}{l}\text { 1. Professional } \\
\text { growth plan }\end{array}$ & $x$ & $x$ & & $x$ & & $x$ & $x$ & $x$ & & $x$ & $x$ & \\
\hline $\begin{array}{l}\text { 2. Leadership } \\
\text { challenges } \\
\text { reflection }\end{array}$ & & $x$ & $x$ & $x$ & & & & $x$ & & & & \\
\hline $\begin{array}{l}\text { 3. Directed Field } \\
\text { Study analysis/ } \\
\text { reflection }\end{array}$ & & $x$ & $x$ & & & & & $x$ & & & & \\
\hline $\begin{array}{l}\text { 4. Community of } \\
\text { practice } \\
\text { presentation }\end{array}$ & & $x$ & $x$ & $x$ & & & $x$ & $x$ & $x$ & & $x$ & \\
\hline $\begin{array}{l}\text { 5. Post-degree } \\
\text { impact plan }\end{array}$ & $x$ & $x$ & $x$ & $x$ & $x$ & $x$ & $x$ & $x$ & $x$ & $x$ & $x$ & \\
\hline \multicolumn{13}{|l|}{$\begin{array}{l}\text { Innovative/ Action } \\
\text { Research } \\
\text { Milestones }\end{array}$} \\
\hline $\begin{array}{l}\text { 1. Research ethics } \\
\text { and CITI } \\
\text { training }\end{array}$ & $x$ & & $x$ & & & & & $x$ & $x$ & & & \\
\hline $\begin{array}{l}\text { 2. Context of } \\
\text { problem } \\
\text { analysis }\end{array}$ & $x$ & $x$ & & $x$ & & & $x$ & $x$ & & $x$ & $x$ & \\
\hline $\begin{array}{l}\text { 3. Research } \\
\text { Conference } \\
\text { presentations }\end{array}$ & & $x$ & $x$ & $x$ & & & $x$ & $x$ & & $x$ & $x$ & \\
\hline $\begin{array}{l}\text { 4. Cycle I report, } \\
\text { written and } \\
\text { presented }\end{array}$ & & $x$ & $x$ & $x$ & $x$ & $x$ & $x$ & $x$ & $x$ & $x$ & $x$ & \\
\hline $\begin{array}{l}\text { 5. Critical papers } \\
\text { portfolio from } \\
\text { courses }\end{array}$ & $x$ & $x$ & $x$ & & $x$ & $x$ & & $x$ & & $x$ & & \\
\hline $\begin{array}{l}\text { 6. Comp. } \\
\text { exam/Diss. } \\
\text { proposal } \\
\text { defense }\end{array}$ & & $x$ & & $x$ & $x$ & $x$ & $x$ & $x$ & $x$ & $x$ & $x$ & $x$ \\
\hline $\begin{array}{l}\text { 7. Dissertation and } \\
\text { defense }\end{array}$ & & $x$ & $x$ & $x$ & $x$ & $x$ & $x$ & $x$ & $x$ & $x$ & $x$ & $x$ \\
\hline $\begin{array}{l}\text { 8. External } \\
\text { dissemination of } \\
\text { research }\end{array}$ & & $x$ & $x$ & & & $x$ & $x$ & $x$ & $x$ & $x$ & $x$ & $x$ \\
\hline
\end{tabular}

with their PoP, CPED Principle 3. Finally, students have shared how they engaged in field-based opportunities to analyze their PoP and employ multiple frameworks as they developed solutions to their PoP, CPED Principle 4

In terms of CPED DC, faculty members viewed research conference presentations as being related to the following design concepts: PoP, scholarly practitioner, inquiry as practice, and laboratories of practice. Students' research presentations focused quite naturally on their PoP and on the work they conducted about their PoP in their laboratories of practice, their workplace settings. Further, the presentations reflected inquiry into their practice. Finally, these online research presentations aided students in developing as scholarly practitioners because they blended practical wisdom with professional skills to work toward a resolution of their PoP by collaborating with others and by disseminating their work to others.

The influence of the CPED GPPD and DC on the remaining leadership and innovation/research milestones is illustrated in a similar way in Table 1. That is to say, an ' $X$ ' at the intersection of the row and column indicated that the particular milestone was viewed as being influenced by or connected to the specific CPED Guiding Principle or Design Concept. 
Table 2. Program Courses by CPED Guiding Principles and Design Concepts

\begin{tabular}{|c|c|c|c|c|c|c|c|c|c|c|c|c|}
\hline & \multicolumn{6}{|c|}{ CPED Guiding Principles } & \multicolumn{6}{|c|}{ CPED Design Concepts } \\
\hline & $\begin{array}{l}1 \\
\text { Equity, } \\
\text { Ethics, } \\
\& \\
\text { Social } \\
\text { Justice } \\
\text { for } \\
\text { POPs } \\
\end{array}$ & $\begin{array}{l}2 \\
\text { Make a } \\
\text { Positive } \\
\text { Difference }\end{array}$ & $\begin{array}{l}3 \\
\text { Collaborate } \\
\text { \& Comm. } \\
\text { Skills to } \\
\text { Build } \\
\text { Partnerships }\end{array}$ & $\begin{array}{l}4 \\
\text { Field-based } \\
\text { Opportunities } \\
\text { to Analyze } \\
\text { POP and Its } \\
\text { Resolution }\end{array}$ & $\begin{array}{l}5 \\
\text { Integrate } \\
\text { Practical \& } \\
\text { Research } \\
\text { Knowledge }\end{array}$ & $\begin{array}{l}6 \\
\text { Generate, } \\
\text { Transform, } \\
\text { and Use } \\
\text { Professional } \\
\text { Knowledge } \\
\text { \& Practice }\end{array}$ & $\begin{array}{l}\text { Problem } \\
\text { of } \\
\text { Practice }\end{array}$ & $\begin{array}{l}\text { Scholarly } \\
\text { Practitioner }\end{array}$ & $\begin{array}{l}\text { Signature } \\
\text { Pedagogy }\end{array}$ & $\begin{array}{l}\text { Inquiry } \\
\text { as } \\
\text { Practice }\end{array}$ & $\begin{array}{l}\text { Laboratories } \\
\text { of Practice }\end{array}$ & $\begin{array}{l}\text { Dissertation } \\
\text { in Practice }\end{array}$ \\
\hline \multicolumn{13}{|l|}{ Summer 1} \\
\hline $\begin{array}{l}\text { TEL } 706 \text { Introduction } \\
\text { to Doctoral Studies }\end{array}$ & & & & $x$ & $x$ & & $x$ & $x$ & & $x$ & & \\
\hline $\begin{array}{l}\text { TEL } 705 \text { Systems } \\
\text { and Leadership }\end{array}$ & $x$ & $x$ & & $\mathrm{x}$ & & & $x$ & $x$ & & & & \\
\hline \multicolumn{13}{|l|}{ Fall 1} \\
\hline $\begin{array}{l}\text { TEL } 703 \text { Innovations } \\
\text { Teaching/Learning }\end{array}$ & & $x$ & $x$ & & $x$ & & $x$ & $x$ & $\mathrm{x}$ & & & \\
\hline $\begin{array}{l}\text { TEL } 711 \text { Strategies } \\
\text { for Inquiry }\end{array}$ & & $x$ & $x$ & $x$ & $x$ & $x$ & $x$ & $x$ & $x$ & $x$ & $x$ & \\
\hline $\begin{array}{l}\text { TEL } 707 \text { Reading the } \\
\text { Research }\end{array}$ & & $x$ & & $x$ & $x$ & & $\mathrm{x}$ & $x$ & & $x$ & $x$ & \\
\hline \multicolumn{13}{|l|}{ Spring 1} \\
\hline $\begin{array}{l}\text { TEL } 702 \text { Dynamic } \\
\text { Contexts of } \\
\text { Education }\end{array}$ & $x$ & $x$ & & & $x$ & & & $x$ & & & & \\
\hline $\begin{array}{l}\text { TEL } 712 \text { Mixed } \\
\text { Methods of Inquiry }\end{array}$ & & $x$ & $x$ & $x$ & $x$ & $x$ & $x$ & $x$ & $x$ & $x$ & $x$ & \\
\hline \multicolumn{13}{|l|}{ Summer 2} \\
\hline $\begin{array}{l}\text { TEL } 704 \text { Leadership } \\
\text { Organizational } \\
\text { Change }\end{array}$ & & $x$ & & & $x$ & & $x$ & $x$ & & $x$ & & \\
\hline $\begin{array}{l}\text { TEL } 709 \text { Directed } \\
\text { Field Study }\end{array}$ & & $x$ & $x$ & & $x$ & & & $x$ & & $x$ & & \\
\hline \multicolumn{13}{|l|}{ Fall 2} \\
\hline $\begin{array}{l}\text { TEL } 701 \text { Advanced } \\
\text { Quantitative Methods }\end{array}$ & & $x$ & & $x$ & $x$ & $x$ & $x$ & $x$ & $\mathrm{x}$ & $x$ & $x$ & \\
\hline $\begin{array}{l}\text { TEL } 713 \text { Advanced } \\
\text { Qualitative Methods }\end{array}$ & $x$ & & & $x$ & $x$ & $x$ & $x$ & $x$ & $x$ & $x$ & $x$ & \\
\hline $\begin{array}{l}\text { TEL } 792 \text { Leader } \\
\text { Scholar Community }\end{array}$ & $x$ & $x$ & $x$ & $x$ & $x$ & $x$ & $x$ & $x$ & $x$ & $x$ & $x$ & $x$ \\
\hline \multicolumn{13}{|l|}{ Spring 2} \\
\hline $\begin{array}{l}\text { TEL } 792 \text { Leader } \\
\text { Scholar Community }\end{array}$ & $x$ & $x$ & $x$ & $x$ & $x$ & $x$ & $x$ & $x$ & $x$ & $x$ & $x$ & $x$ \\
\hline TEL 780 Elective $^{a}$ & & $x$ & & & $x$ & & $x$ & $x$ & & $x$ & & $x$ \\
\hline TEL 780 Elective $^{a}$ & & $x$ & & & $x$ & & $x$ & $x$ & & $x$ & & $x$ \\
\hline \multicolumn{13}{|l|}{ Summer 3} \\
\hline $\begin{array}{l}\text { TEL } 708 \\
\text { Collaborative } \\
\text { Approaches to... }\end{array}$ & & $x$ & $x$ & & $x$ & & & $x$ & & $x$ & $x$ & \\
\hline TEL 780 Elective $^{a}$ & & $x$ & & & $x$ & & $x$ & $x$ & & $x$ & & $x$ \\
\hline $\begin{array}{l}\text { Tel } 791 \text { Innov. in } \\
\text { Dissem. Research }\end{array}$ & & & & $x$ & & $x$ & $x$ & $x$ & & $x$ & $x$ & \\
\hline \multicolumn{13}{|l|}{ Fall 3} \\
\hline $\begin{array}{l}\text { TEL } 799 \text { Dissertation } \\
\text { in Practice }\end{array}$ & $x$ & $\mathrm{x}$ & $x$ & $x$ & $x$ & $x$ & $x$ & $\mathrm{x}$ & $x$ & $x$ & $x$ & $x$ \\
\hline \multicolumn{13}{|l|}{ Spring 3} \\
\hline $\begin{array}{l}\text { TEL } 799 \text { Dissertation } \\
\text { in Practice }\end{array}$ & $x$ & $x$ & $x$ & $x$ & $x$ & $x$ & $x$ & $x$ & $x$ & $x$ & $x$ & $x$ \\
\hline
\end{tabular}

Note: a-Electives can be selected from courses such as Using Qualitative Analysis in Grounded Theory Coding, Survey Development, Research in the Postsecondary Education Context, and Case Study Research. ${ }^{-}$--The full title of the course is Collaborative Approaches to Data-informed Decision Making. ${ }^{c}$-The full title of the course is Innovations in Disseminating Research. 


\section{Influence of the CPED Framework on Program Courses}

To demonstrate the influence of the CPED Framework on courses in the ASU EdD in Leadership and Innovation program, I have provided two examples. First, I have discussed the influences of the Framework on TEL 712- Mixed Methods of Inquiry, a methodology-type course students take during the program. In this course, students have engaged in action research efforts that have included developing and implementing a small-scale intervention on their PoP. Numerous CPED GPPD have influenced the course and the actions students have taken in the course. Specifically, students have been engaged in conducting a small-scale intervention that was a means to resolve their PoP. This has allowed them to analyze their PoP more fully and begin to develop useful solutions, CPED Principle 4. Moreover, this intervention work has required them to collaborate with their communities and build partnerships, CPED Principle 3, around the PoP as they applied this new knowledge to make a positive difference in the lives of individuals, organizations, or communities-CPED Principle 2. Additionally, as students have conducted their efforts in TEL 712, they have integrated practical and research knowledge and connected theory with inquiry, CPED Principle 5 , and engaged in generating and using professional knowledge in their practice, CPED Principle 6. In Table 2, I have demonstrated how the CPED Framework has influenced the courses in our program. Again, an ' $X$ ' in the table indicated that the CPED Framework component influenced the course.

With respect to design concepts, students have applied an intervention to their PoP in an attempt to resolve it during this cycle of action research, which was one of the program's signature pedagogies. As a result, students have engaged in inquiry as practice, a CPED DC, "by using various research, theories, and professional wisdom ... [to] design innovative solutions to address the problems of practice" (CPED, 2010, para. 11). Further, students have demonstrated inquiry as practice as they "gather, organize, judge, aggregate, and analyze situations, literature and data with a critical lens" (CPED 2010, para. 11). Because students have been required to conduct this work in their workplace settings, they have made use of CPED's laboratories of practice design concept defined, in part, by, "settings where theory and practice inform and enrich each other .... where ideas-formed by the intersection of theory, inquiry, and practice-can be implemented, measured, and analyzed for the impact made" (CPED, 2010, para. 12). Thus, in conducting this effort, students have developed as scholarly practitioners because they have "blend[ed] practical wisdom with professional skills and knowledge to name, frame, and solve problems of practice [as] they use practical research and applied theories as tools ... to resolve problems of practice collaborating with key stakeholders ..." (CPED 2010, para. 9).

Second, TEL 799-Dissertation in Practice (DiP), the culminating activity in the program, has been guided by all the CPED principles and design concepts. I will not provide a detailed explanation because much of it would reflect the description for TEL 712 provided previously. In the following discussion, I merely amplify some aspects not well represented in the discussion of TEL 712 . First, students' DiPs tended to examine questions of equity and bringing about solutions to complex PoPs, CPED Principle 1. The DiP has been implemented as a scholarly enterprise that affects a PoP, which was consistent with the CPED Design Concept of DiP. With respect to how the dissertation represented inquiry as practice, consider that CPED's (2010) definition of inquiry as practice included the notion that "the center of inquiry as practice is the ability to use data to understand the effects of innovation" (para. 11). Thus, because students have acquired more well-developed skills with respect to gathering and analyzing data, those completing the DiP were now more capable of using the data to determine the effectiveness of their innovation.

\section{CONCLUSION}

In this essay, I convey the pervasive influence that the CPED Framework has on our EdD program. The CPED Framework influences the more fundamental aspects of our program such as students' focus on a problem of practice and use of cohort structure in program delivery as well as the more complex facets such as signature pedagogies like CAR and LSCs. Moreover, the CPED Framework also influences the program milestones and courses in the program. Use of the CPED Framework in this way allows students to participate in a coherent, practice-focused program that is helpful as they participate in the program and useful long afterword as graduates continue to draw upon the knowledge and skills they learn to inform their professional, education, and leadership practices.

Finally, it may be instructive to consider your own program in light of the CPED Framework. For example, how does the CPED Framework influence general, global program components, such as use of cohorts or other program features? Further, how does the CPED Framework shape your program milestones and assessments of those milestones? Finally, how does the CPED Framework affect your program courses? Undoubtedly, there are strong connections, but I suspect most of those are implicit. In our efforts to construct the online version of our program, we thoughtfully and thoroughly considered how the courses fit together and how the CPED Framework influenced them. Similarly, as we considered the development and implementation of assessment of our program milestones, we carefully considered how the CPED Framework shaped them. As a result, faculty members were able to create and continue to deliver a more coherent, practitioner-oriented program, which benefits students.

\section{REFERENCES}

Ali, A., \& Kohun, F. (2007). Dealing with social isolation to minimize doctoral attrition-a four stage framework. International Journal of Doctoral Studies, 2, 33-49.

Amrein-Beardsley, A., Zambo, D., Moore, D. W., Buss, R. R., Perry, N. J., Painter, S. R., Carlson, D. L., Foulger, T. S., Olson, K., \& Puckett, K. S. (2012). Graduates respond to an innovative educational doctorate program. Journal of Research on Leadership Education, 7(1), 98-122. doi: $10.1177 / 1942775112440630$

Buss, R. R. (2018). Using action research as a signature pedagogy to develop EdD students' inquiry as practice skills. Impacting Education: Journal on Transforming Professional Practice, 3, 23-31. Online journal. doi: 10.5195/ie.2018.46

Buss, R. R., \& Allen, J. G. (2018). Leader scholar communities: Supporting EdD students' dissertation in practice efforts. Manuscript submitted for review.

Buss, R. R., \& Zambo, D. (2016). Using action research to develop educational leaders and researchers. In J. A. Perry (Ed.), The EdD and the scholarly practitioner (pp. 137-152). Charlotte, NC: Information Age Publishing.

Buss, R. R., Zambo, R., Zambo, D., Perry, J. A., \& Williams, T. R. (2017). Faculty members' responses to implementing new EdD programs. 
Studies in Higher Education, 42(9), 1624-1640. doi: 10.1080/03075079.2015.1113951

Buss, R. R., Zambo, R., Zambo, D., \& Williams, T. R. (2014). Developing researching professionals in an EdD program: From learners and leaders to scholarly and influential practitioners. Higher Education, Skills and Work-based Learning, 4, 137-160.doi: 10.1108/HESWBL-11-2013-0022

Carnegie Project on the Education Doctorate (CPED). (2009). CPED guiding principles for program development. Retrieved from https://c.ymcdn.com/sites/cpedinitiative.siteym.com/resource/resmgr/CPED_Framework.pdf

Carnegie Project on the Education Doctorate. (CPED). (2010). CPED design concepts. Retrieved from https://c.ymcdn.com/sites/cpedinitiative.siteym.com/resource/resmgr/CPED_Framework.pdf

De Lisi, R. (2013). Reflection, reconstruction, and transformation of the EdD: A dean's perspective. Planning and Changing: An Educational Leadership and Policy Journal, 44, 127-139.

Hoffman, R. L., \& Perry, J. A. (2016). The CPED framework: Tools for change. In J. A. Perry (Ed.), The EdD and the scholarly practitioner: The CPED path (pp. 13-25). Charlotte, NC: Information Age Publishing.

Levine, A. (2005). Educating school leaders. Princeton: NJ: The Woodrow Wilson National Fellowship Foundation.

Macintyre Latta, M., \& Wunder, S. (2012). Investing in the formative nature of earning: Redirecting, mediating, and generating education practice-aspolicy. In M. Macintyre Latta \& S. Wunder (Eds.), Placing practitioner knowledge at the center of teacher education: Rethinking the policies and practices of the education doctorate (pp. 3-26). Charlotte, NC: Information Age Publishing.

Mertler, C. A., \& Henriksen, D. (2018). Creative and innovative solutions to accommodate the growth of a professional practice doctoral program. Impacting Education: Journal of Transforming Professional Practice, 3 , 36-44.

Olson, K., \& Clark, C. M. (2009). A signature pedagogy in education: The leader-scholar community. Educational Researcher, 38, 216-221.

Perry, J. A. (2012). To EdD or not to EdD? Kappan, 94(1), 41-44.

Perry, J. A. (2016). The new education doctorate: Preparing the transformational leader. In J. A. Perry (Ed.), The EdD and the scholarly practitioner: The CPED path (pp. 1-10). Charlotte, NC: Information Age Publishing

Perry, J. A., \& Imig, D. G. (2008). A stewardship of practice in education. Change, 40(6), 42-48.

Perry, J. A., Zambo, D., \& Wunder, S. (2015). Understanding how schools of education have redesigned the doctorate of education. Journal of School Public Relations, 36, 58-85.

Rueda, R., Sundt, M., \& Picus, L. O. (2013). Developing scholarly practitioners: Lessons from a decade-long experiment. Planning and Changing: An Educational Leadership and Policy Journal, 44, 252-265.

Sawyer, R. D. (2013). Learning to walk the talk: Designing a teacher leadership EdD program as a laboratory of practice. Planning and Changing: An Educational Leadership and Policy Journal, 44, 208-220.

Susman Israel, M., Sostak, S., Stewart, F. P., \& Bazzi-Moughania, A. (2016). Creating an EdD structure, program, and process fulfilling the needs of doctoral candidates and the communities they will serve: Applying lessons learned from the redesign of a principal preparation program. In V. A. Storey \& K. A. Hesbol (Eds.), Contemporary approaches to dissertation development and research methods (pp. 70-87). Hershey, PA: IGI Global.

Shulman, L. S. (2005). Signature pedagogies in the professions. Daedalus, 134(3), 52-59.

Shulman, L. S., Golde, C. M., Bueschel, A. C., \& Garabedian, K. J. (2006). Reclaiming education's doctorates: A critique and a proposal. Educational Researcher, 35(3), 25-32.

Wenger, E. (1998). Communities of practice: Learning, meaning, and identity. New York, NY: Cambridge University Press.

Wenger, E., McDermott, R., \& Snyder, W. M. (2002). Cultivating communities of practice. Boston, MA: Harvard Business School Press.

Zambo, R., Zambo, D., Buss, R. R., Perry, J. A., \& Williams, T. R. (2014) Seven years after the call: Students' and graduates' perceptions of the re-envisioned Ed.D. Innovative Higher Education, 39, 123-137. doi: $10.1007 / \mathrm{s} 10755-013-9262-3$ 